\title{
Impact of Landmark Identification and Standard Measurement Error on Cephalometric Analysis Using a Mathematical Simulation Model
} Impacto da Identificação do Ponto Anatômico e do Erro Padrão de Mensuração na Análise Cefalométrica Utilizando um Modelo de Simulação Matemática

Eduardo Luiz Delamare', Gabriela Salatino Liedke², Mariana Boessio Vizzotto ${ }^{3}$, Heraldo Luis Dias da Silveira ${ }^{4}$, Dalva Maria Pereira Padilha $^{5}$, José Luís Duarte Ribeiro ${ }^{6}$, Priscila Fernanda da Silveira ${ }^{7}$, Heloisa Emilia Dias da Silveira ${ }^{8}$

\section{Abstract}

Objective: To assess, using a mathematical simulation model, the participation of each coordinate involved in the formation of cephalometric angles and to determine the extent to which errors in the identification of cephalometric landmarks can, individually and collectively, influence the measurement of these angles.

Material and Methods: The reference values and standard errors of 13 landmarks obtained from the analysis of 30 cephalograms were used. For each landmark, 1000 observations were simulated using the Monte Carlo method. On the basis of linear regression models, equations designed to estimate measurement errors due to landmark identification errors were obtained and analysed.

Results: The coordinates most involved in the formation of the angles SNA, SNB, ANB, FMA, PPL, DFC, and AEF were $\mathrm{Ny}, \mathrm{Ny}, \mathrm{Ax}$, Goy, Poy, Poy, and Ptmx, respectively, and the standard measurement errors for these angles were 1.2, 0.9, 0.8, 1.6, 1.5, 1.5, and 1.4 , respectively.

Conclusion: The standard measurement error of the angle depends on the geometric impact coefficient and the standard error of the coordinates involved in the formation of the angles, and the geometric impact coefficient varies according to the angle analysed.

Keywords: Cephalometry. Anatomic landmarks. Statistics and numerical data.

\section{Resumo}

Objetivos: Avaliar, empregando um modelo matemático de simulação, a participação de cada coordenada envolvida na formação de ângulos cefalométricos, assim como determinar a extensão da influência dos erros na identificação dos pontos cefalométricos, individual e coletivamente, na mensuração destes ângulos.

Materiais e métodos: Foram utilizados os valores de referência e os erros padrão de 13 pontos anatômicos obtidos a partir da análise de 30 cefalogramas. Para cada ponto anatômico, foram simuladas 1000 observações utilizando o método de Monte Carlo. Com base em modelos de regressão linear, foram obtidas e analisadas equações destinadas a estimar os erros de medição devido a erros na identificação dos pontos cefalométricos.

Resultados: As coordenadas mais envolvidas na formação dos ângulos SNA, SNB, ANB, FMA, PPL, DFC, e AEF foram Ny, Ny, Ax, Goy, Poy, Poy, e Ptmx, respectivamente, e os erros padrão de mensuração destes ângulos foram 1,2; 0,$9 ; 0,8 ; 1,6 ; 1,5 ; 1,5$ e 1,4, respectivamente.

Conclusões: $O$ erro padrão de mensuração de cada ângulo cefalométrico depende do coeficiente de impacto geométrico e do erro padrão das coordenadas dos pontos anatômicos envolvidos na formação dos mesmos, sendo que o coeficiente de impacto geométrico varia de acordo com o ângulo analisado.

Palavras-chave: Arcada osseodentária. Pontos de referência anatômicos. Estatística e dados numéricos.
${ }^{1}$ Mestre em Odontologia.

${ }^{2}$ Mestre em Odontologia; Departamento de Cirurgia e Ortopedia; Faculdade de Odontologia da UFRGS, Porto Alegre, RS, Brasil.

${ }^{3}$ Doutora em Odontologia, Professora Adjunta da Faculdade de Odontologia da UFRGS; Departamento de Cirurgia e Ortopedia; Faculdade de Odontologia da UFRGS, Porto Alegre, RS, Brasil.

${ }^{4}$ Doutor em Odontologia, Professor Adjunto da Faculdade de Odontologia da UFRGS; Departamento de Cirurgia e Ortopedia; Faculdade de Odontologia da UFRGS, Porto Alegre, RS, Brasil.

${ }^{5}$ Doutora em Odontologia, Professora Associada da Faculdade de Odontologia da UFRGS; Departamento de Odontologia Preventiva e Social; Faculdade de Odontologia da UFRGS, Porto Alegre, RS, Brasil

${ }^{6}$ Doutor em Engenharia, Professor Associado da Escola de Engenharia da UFRGS; Departamento de Engenharia de Produção e Transportes; Escola de Engenharia da UFRGS, Porto Alegre, RS, Brasil.

7 Aluna de Mestrado em Odontologia; Departamento de Cirurgia e Ortopedia; Faculdade de Odontologia da UFRGS, Porto Alegre, RS, Brasil

${ }^{8}$ Doutora em Odontologia, Professora Associada da Faculdade de Odontologia da UFRGS; Departamento de Cirurgia e Ortopedia; Faculdade de Odontologia da UFRGS, Porto Alegre, RS, Brasil.

Correspondência: Priscila Fernanda da Silveira

Endereço: Rua Ramiro Barcelos 2492, Porto Alegre, RS, Brasil, CEP 90035-003

prifsilveira@yahoo.com.br

E-mail: prifsilveira@yahoo.com.br

Data de Submissão: 25/03/2013

Data de Aceite: 28/08/2013

\section{Introduction}

Cephalometric analysis is largely used for diagnosis, planning and follow up in orthodontic, facial orthopaedic or surgicalorthognathic treatments. In spite of oral and maxillofacial area is moving towards 3D-images, bidimensional cephalograms are still in use and, because it is an established method, have reproducibility with the three-dimensional analysis and, especially by the lower radiation dose received by patients, are recommended if the patient has no need for a tomographic examination (OZ et al., 2011; LIEDKE et al., 2012). Therefore, the accurate recording, correct interpretation of this analysis and understanding of its limitations are essential for the achievement of its objectives (CHEN et al., 2000; KAMOEN et al., 2001).

Regardless of the kind of 2D-image acquisition and processing, the identification of landmarks is performed manually (CHEN et al., 2004; GREINER et al., 2007; KUMAR et al., 2008; YU et al., 2008; LIEDKE et al., 2012). Because of the subjective nature of this process, it is generally recognised that the occurrence of errors is an aspect that must always be taken into account (KAMOEN et al., 2001; DA SILVEIRA; SILVEIRA, 2006). Moreover, reports confirm that 
the variability of landmark identification follows characteristic patterns and is directly associated with measurement inaccuracies, which vary independently from the chosen imaging method (CHEN et al., 2004; ARPONEN et al., 2008; YU et al., 2008; DELAMARE et al., 2010).

Measurement errors derived from inaccurate landmark identification are an expectable limitation of cephalometric analysis. However, the extents of these errors and its repercussions with respect to angular measurements have not been fully explored in the literature. Therefore, the objective of this study was to assess, through a mathematical simulation model, the participation of each coordinate involved in the formation of cephalometric angles and to determine the extent to which errors in the identification of cephalometric landmarks can, individually and collectively, influence the measurement of these angles.

\section{Materials and Methods}

This research was approved by the Institutional Review Board of the Federal University of Rio Grande do Sul, Brazil. Cephalometric radiograph and CBCT (cone beam computed tomography) synthetized cephalogram were randomly selected from 10 subjects who presented for orthodontic treatment at the Faculty of Dentistry and needed those exams. All the patients or their guardians signed an informed consent form.

Cephalometric radiographs were taken with a Cranex Tome (Soredex, Milwaukee, WI, USA), operating with $70 \mathrm{kV}, 10 \mathrm{~mA}$ and 0.6 $\mathrm{s}$ and were scanned into JPEG digital format using an Astra $2400 \mathrm{~S}$ scanner (UMAX, Dallas, TX, USA) with 300 dpi resolution. The CBCT images were obtained from an i-CAT scanner (Imaging Sciences International, Hatfield, PA, USA) operating with $129 \mathrm{kVp}, 4.7 \mathrm{~mA}, 40 \mathrm{~s}$ and 0.25 voxel resolution. Using $\mathrm{i}-\mathrm{Cat}$ Vision software, the skull was oriented with midsagittal plane perpendicular and Frankfurt plane parallel to the ground, simulating the cephalostat position; then, two synthetized cephalograms were constructed: one with the whole skull volume and one with half skull volume. Thus, the study comprised a sample of 30 images: 10 cephalometric radiographs and 20 CBCT synthetized cephalograms.

Five calibrated dentists performed the cephalometric analysis using Radiocef software (RadioMemory, Belo Horizonte, MG, Brazil). Theirs standard deviation and a reference value for the $\mathrm{X}$ - and Y-coordinates of each landmark used in this study (Table 1) were saved (Table 2). Therefore, the estimated error adopted corresponds to a reliable reproduction of values that can be expected from a population of experienced observers who analyse cephalograms generated from CBCT images or conventional radiographs.

Using the Monte Carlo method, the reference values of each landmark generated 1000 new simulated coordinates for each landmark. Subsequently, the simulated landmarks produced angular measurements (Table 1), which were calculated using the Microsoft Excel 2007 arctangent (ATAN) function. Then, the observation errors for all the landmark coordinates involved in the calculation of each angle were deliberately modified (within values ranging from 0.2 to 2.0 $\mathrm{mm}$ ) and the corresponding simulated angle measurement was recorded. This observation error range was adopted in order to reproduce the performance of a group consisting of highly and poorly reproducible observers. From the results of this experiment, it was possible to estimate a geometric impact coefficient for each landmark coordinate, representing the extent to which this coordinate affects the angle (Table 3).

The equations designed to estimate the standard measurement errors due to landmark identification errors were based on multiple linear regression models and are presented below. Essentially, the geometric impact coefficient of each coordinate is multiplied by the square of its standard error (E). The result is the standard measurement error of the angle.

$$
\begin{aligned}
& \text { Error } S N A=\sqrt{0.78 \times E S y^{2}+0.95 \times E N x^{2}+1.08 \times E N y^{2}+1,33 \times E A x^{2}} \\
& \left(R^{2}=98.68 \%\right) \\
& \text { Error } S N B=\sqrt{0.79 \times E S y^{\mathbf{2}}+0.25 \times E N x^{2}+0.86 \times E N y^{\mathbf{2}}+0.40 \times E B x^{2}} \\
& \left(R^{2}=98.97 \%\right) \\
& \text { Error } A N B=\sqrt{1.32 \times E A x^{2}+0.27 \times E N x^{2}+0.38 \times E B x^{2}} \\
& \left(R^{2}=98.81 \%\right) \\
& \text { Error FMA }=\sqrt{0.66 \times E P o y^{2}+0.95 \times E G o y^{2}+0.64 \times E O r y^{2}+0.89 \times E M e y^{2}} \\
& \left(R^{2}=90.00 \%\right) \\
& \text { Error PPL }=\sqrt{0.68 \times E P o y^{2}+0.72 \times E O r y^{2}+1.56 \times E E n a y^{2}+1.56 \times E E n p y^{2}} \\
& \left(R^{2}=95.70 \%\right) \\
& \text { Error } D F C=\sqrt{0.66 \times E P O y^{2}+0.59 \times E O r y^{2}+0.17 \times E B a x^{2}+0.39 \times E B a y^{2}+0.16 \times E N x^{2}+0.47 \times E N y^{2}} \\
& \left(R^{2}=93.00 \%\right)
\end{aligned}
$$

Table 1. Landmarks and angular measurements used in the present study.

\begin{tabular}{ll}
\hline Landmarks & \\
\hline S & Sella \\
A & Nasion \\
B & Point A \\
Po & Point B \\
Or & Porion \\
Go & Orbitale \\
Me & Gonion \\
Ans & Menton \\
Pns & Anterior nasal spine \\
Ba & Posterior nasal spine \\
Ptm & Basion \\
Gn & Pterigomaxillary fissure \\
\hline Angular measurements \\
\hline SNA & Position of maxilla relative to anterior cranial base \\
SNB & Position of mandible relative to anterior cranial \\
ANB & base \\
FMA & Relative position of maxilla to mandible \\
PPL & Frankfort mandibular angle \\
DFC & Palatal plane \\
AEF & Facial angle \\
\hline &
\end{tabular}


All the data obtained during the experiment were used for the formulation of the regression models. The statistical analysis was carried out using SPSS $®$ Version 15.0 for Windows and Microsoft Excel® 2007 for Windows.

Table 2: Average standard deviation and reference values for each landmark in $X$ and $Y$ axis obtained for 30 cephalograms in 10 patients.

\begin{tabular}{ccccc}
\hline Landmark & \multicolumn{2}{c}{ Standard deviation } & \multicolumn{2}{c}{ Reference values } \\
\hline S & X & Y & X & Y \\
N & 0,3 & 0,32 & 46,2 & 35,2 \\
A & 0,38 & 0,86 & 108,1 & 23 \\
B & 0,73 & 0,84 & 112,2 & 72,3 \\
Po & 0,24 & 1,13 & 110,4 & 112,8 \\
Or & 0,84 & 1,04 & 25 & 53 \\
Go & 1,35 & 0,99 & 96,4 & 49,4 \\
Me & 1,1 & 1,15 & 45,9 & 105,3 \\
Ans & 0,48 & 0,21 & 105,3 & 129 \\
Pns & 1 & 0,55 & 115 & 67,3 \\
Ba & 1,1 & 0,48 & 67,3 & 73,3 \\
Ptm & 0,82 & 0,95 & 25 & 71,1 \\
Gn & 0,93 & 1,42 & 63 & 49,1 \\
& 0,25 & 0,24 & 108,8 & 127,5 \\
\hline
\end{tabular}

\section{Results}

Table 3 presents the coordinates that are most involved in the angle formation and the impact that each one has on the measurement. It was observed that the influence of a coordinate on the measured value of the angle depends on its geometric impact coefficient and standard error. In the case of the SNB angle, the Ny coordinate had the most impact on the value of the angle because its geometric impact coefficient $(0.86)$ and standard error $(0.73)$ were both high. In the case of the PPL angle, although the ANSy coordinate had the greatest geometric impact coefficient (1.56), its standard error was low (0.30); in contrast, the standard error of the Poy coordinate was high (1.08), making it the most influential coordinate in the final determination of this angle. A similar logic can be applied to the other angles and coordinates.

The standard measurement errors observed for the angles SNA, SNB, ANB, FMA, PPL, DFC, and AEF were 1.2, 0.9, 0.8, 1.6, $1.5,1.5$, and 1.4, respectively (Table 3 ).

The other coordinates used to obtain the angles concerned had very little influence on the angle formation, as demonstrated by linear regression, even when a standard error was observed in their identification. Hence, they are not listed in Table 3.
Table 3. Coordinates most involved on each angle formation and the percentual (\%) designated for each one; the geometric impact coefficient and the final impact of each coordinate on angle formation; and the standard measurement error for each angle.

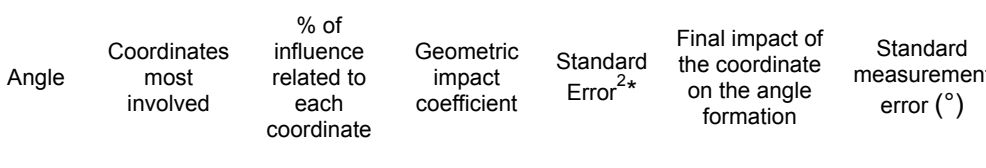

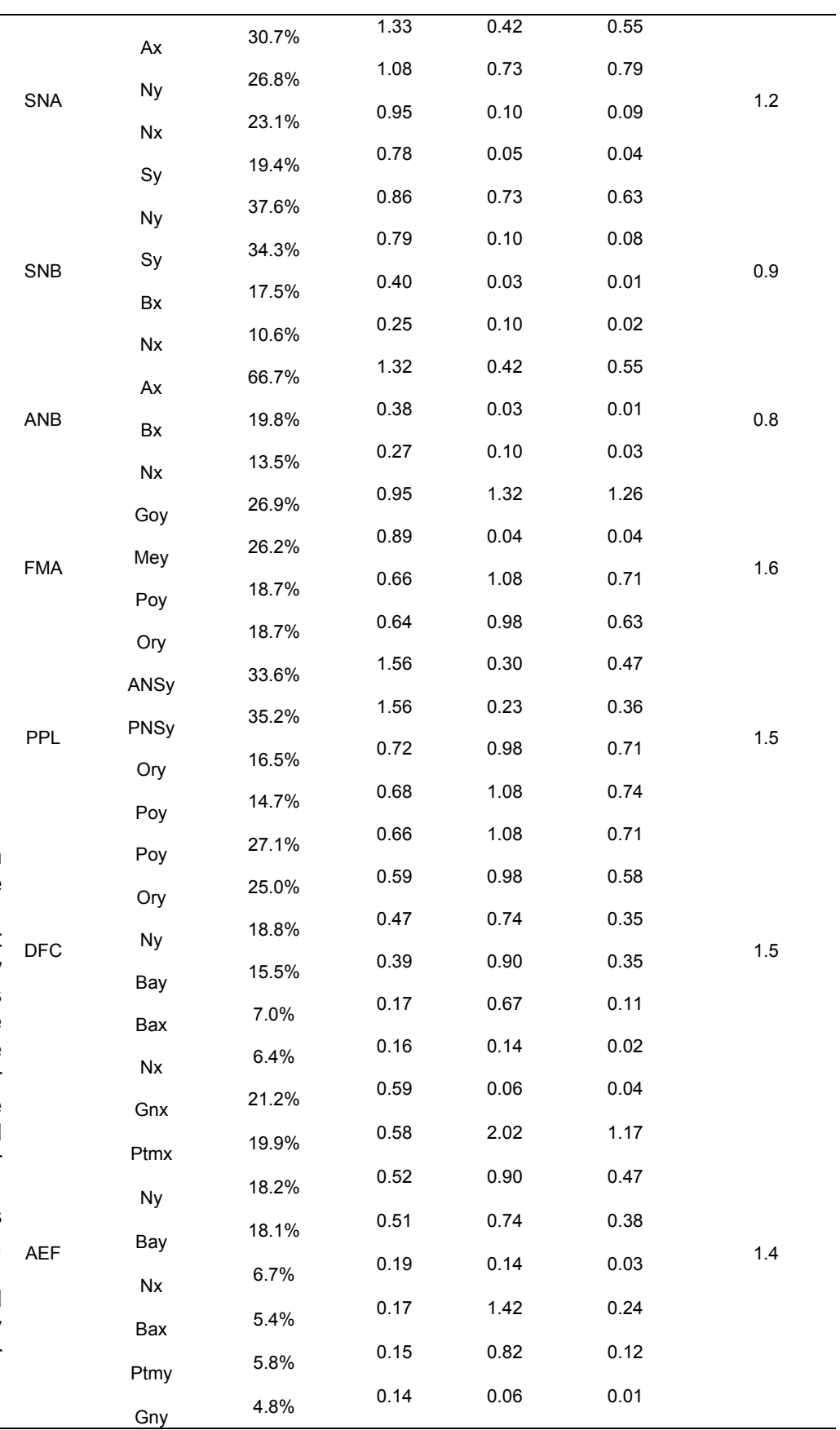

Rev. Fac. Odontol. Porto Alegre, v. 53, n. 3, p. 1-5, set./dez., 2012. 


\section{Discussion}

The incorrect identification of anatomical points on the cephalogram is one of the most common causes of error on a cephalometric analysis, even when calibrated observers perform the landmark identification (STABRUN; DANIELSEN, 1982; TNG et al., 1994; KAMOEN et al., 2001; DA SILVEIRA; SILVEIRA, 2006). Considering this inherent presence of error, the present study aimed to mathematically evaluate the behaviour of seven cephalometric angles in order to identify the coordinates most closely related to their formation and the impact that an error would have on the final result of the angle. The Monte Carlo method was used to simulate the identification of landmarks. This allowed to assess the performance of a large number of observers and enabled further evaluation of the impact of each coordinate on the formation of the angles by linear regression.

If all cephalometric landmarks were equally difficult to identify, the error in the measurement of an angle would be related solely to its geometric configuration. Thus, the coordinate with the highest geometric impact coefficient would have the greatest contribution to the error for a given angle. However, from Table 3, it can be seen that the coordinate with the highest geometric impact coefficient in relation to angle formation is not necessarily the one that causes the greatest change in the angle in the case of erroneous marking. The variation also depends on the standard error for each landmark. Certain landmarks and coordinates are much more difficult to identify. In order to take this into account, the simulation model considered the standard error, which represents the difficulty of determining each coordinate for each landmark. The standard error adopted is in agreement with the findings reported in the literature (BAUMRIND; FRANTZ, 1971; TNG et al., 1994; HAGG et al., 1998; KAMOEN et al., 2001). Therefore, if the geometric impact coefficient is high, but the standard error is low, the change in the angle may not be as significant as the change that is caused by a landmark with a high standard error (e.g., the PPL angle case).

While analysing the pattern of identification of certain cephalometric landmarks, some authors noted a greater variability in the identification of the coordinates By, ANSx e Ptmy (KAMOEN et al., 2001). In this study, these same landmarks were found to have high standard errors, indicating a higher degree of difficulty in their identification. However, the linear regression results indicated that these coordinates had only a low or negligible influence on the formation of the angles SNB, PPL, and AEF, respectively. It can be explained by the fact that the inclusion of the coordinates forming each angle depends strongly on the geometric configuration of the angle.

The standard measurement errors calculated from the equations, and presented in Table 3 , indicate the average degree of expected error for each angle when expert observers perform a cephalometric analysis. These calculations took into account the geometric impact coefficient and the standard error of the coordinates involved in the formation of the angles. It is verified that, with the exception of the angles SNB and ANB, the standard measurement errors were greater than one degree. Thus, the dentist needs to be aware of the possibility of the presence of errors in the results of angular measurements as well as the maximum possible magnitude of these errors. This fact should be considered when interpreting the results, since depending on the cephalometric factor analysed, a difference of one degree may represent a change in the diagnosis and/or treatment plan for a particular patient.

Kamoen et al. (2001) have proposed a calculation for the measurement errors in cephalometric factors on the basis of the variability of the results of cephalometric measurements found in two instances of landmark identification. However, the authors did not consider the geometric configuration of the angles and, therefore, the cephalometric points could have had different impacts on their formation. In this study, it was observed that the same variation in different coordinates of different landmarks has a distinct impact on each cephalometric angle.

There are many reports in the literature describing the point where the error occurs in the identification of landmarks during a cephalometric analysis. However, it has not been clearly determined to what extent an error in marking a cephalometric landmark influences the formation of each angle. This study examined the relationship between the geometry of each angle and the standard error of the landmarks coordinates involved in the angle formation. The results show clearly and in detail which $X$ and $Y$ coordinates are the most sensitive to error from the viewpoint of having a significant impact on the measurement of the respective angle.

Recognizing the importance and exact consequences of these levels of variability over cephalometric angles is essential. This will lead to a better interpretation of results, as the resultant estimations of value ranges can account for landmark complexity, and consequently, be more reliable. These findings might also assist professionals and professors engaged in teaching by demonstrating precisely which landmarks and corresponding axes are most likely to cause errors during cephalometric analyses.

\section{Conclusion}

The standard measurement error of the angle is dependent on the geometric impact coefficient and standard error of the coordinates that are involved in the formation of the angle, and the geometric impact coefficient varies according to the angle analysed. Thus, it is recommended that all cephalometric studies, scientific or clinical, that perform cephalometric comparisons must take into consideration not only the calibration of the examiner but also the impact that different landmarks have on the cephalometric factor analysed.

\section{References}

ARPONEN, $\mathrm{H}$. et al. Reliability of cranial base measurements on lateral skull radiographs. Orthod. Craniofac. Res., Oxford, v. 11, no. 4, p. 201-210, 2008.

BAUMRIND, S.; FRANTZ, R. C. The reliability of head film measurements. 1. Landmark identification. Am. J. Orthod., St. Louis, v. 60 , no. 2 , p. $111-127,1971$.

CHEN, Y. J. et al. Comparison of landmark identification in traditional versus computer-aided digital cephalometry. Angle Orthod., Appleton, v. 70, no. 5, p. 387-392, 2000.

CHEN, Y. J. et al. The effects of differences in landmark identification on the cephalometric measurements in traditional versus digitized cephalometry. Angle Orthod., Appleton, v. 74, no. 2, p. 155-161, 2004.

DA SILVEIRA, H. L.; SILVEIRA, H. E. Reproducibility of cephalometric measurements made by three radiology clinics. Angle Orthod., Appleton, v. 76, no. 3, p. 394-399, 2006.

DELAMARE, E. L. et al. Influence of a programme of professional calibration in the variability of landmark identification using cone beam computed tomography synthesized and conventional radiographic 
cephalograms. Dentomaxillofac. Radiol., Erlangen, v. 39, no. 7, p. 414-423, 2010.

GREINER, M. et al. Variance of landmarks in digital evaluations: comparison between CT-based and conventional digital lateral cephalometric radiographs. J. Orofac. Orthop., München, v. 68, no. 4, p. 290-298, 2007.

HAGG, U. et al. The reproducibility of cephalometric landmarks: an experimental study on skulls. Aust. Orthod. J., Brisbane, v. 15, no. 3, p. 177-185, 1998.

KAMOEN, A. et al. The clinical significance of error measurement in the interpretation of treatment results. Eur. J. Orthod., Oxford, v. 23, no. 5, p. 569-578, 2001.

KUMAR, V. et al. In vivo comparison of conventional and cone beam CT synthesized cephalograms. Angle Orthod., Appleton, v. 78, no. 5, p. $873-879,2008$.

LIEDKE, G. et al. Comparative study between conventional and cone beam CT synthesized half and total skull cephalograms. Dentomaxillofac. Radiol., Erlangen, v. 41, no. 2, p. 136-142, 2012.

OZ, U. et al. Comparison of linear and angular measurements using two-dimensional conventional methods and three-dimensional cone beam CT images reconstructed from a volumetric rendering program in vivo. Dentomaxillofac Radiol, v. 40, no. 8, p. 492-500, 2011.

STABRUN, A. E.; DANIELSEN, K. Precision in cephalometric landmark identification. Eur J Orthod, v. 4, no. 3, p. 185-196, 1982.

TNG, T. T. et al. Validity of cephalometric landmarks. An experimental study on human skulls. Eur. J. Orthod., Oxford v. 16, no. 2, p. 110120, 1994.

YU, S. H. et al. Reliability of landmark identification on monitordisplayed lateral cephalometric images. Am J Orthod Dentofacial Orthop, St. Louis, v. 133, no. 6, p. 790.e1-6; discussion e1, 2008.

Rev. Fac. Odontol. Porto Alegre, v. 53, n. 3, p. 1-5, set./dez., 2012. 